\title{
Recall dan Precision Pada Sistem Temu Kembali Informasi Online Public Access Catalogue (OPAC) di Perpustakaan
}

\author{
$\operatorname{Martin}^{1}$, Lala Nilawati ${ }^{2}$ \\ ${ }^{1}$ Sekolah Tinggi Manajemen Informatika dan Komputer Nusa Mandiri \\ e-mail: martin.auf@gmail.com \\ ${ }^{2}$ Universitas Bina Sarana Informatika \\ e-mail: lala.lni@bsi.ac.id
}

\begin{abstract}
Cara Sitasi: Martin, \& Nilawati, L. (2019, Maret). Recall dan Precision Pada Sistem Temu Kembali Informasi Online Public Access Catalogue (OPAC) di Perpustakaan. (S. Dalis, Ed.) Paradigma - Jurnal Komputer dan Informatika, 21(1), 77-84. doi:10.31294/p.v21i1.5064
\end{abstract}

\begin{abstract}
The National Human Rights Commission Library in the development of technology utilizes an information retrieval system for online public access (OPAC), to measure the effectiveness of a retrieval system. This study aims to determine the effectiveness of information retrieval systems through recall and precision assessment. The method of this research is a quantitative method with the type of experimental approach. The research subject is a collection stored in the Library database, while the object is the SLiMS application information retrieval system. Methods of collecting data using observation, tests, documentation, and interviews. The results showed that the average recall and precision values in the retrieval system at the National Human Rights Commission Library through a simple search feature obtained an average recall value of $99.8 \%$ and an average precision of $99.6 \%$. From the results obtained, the information retrieval system at the National Human Rights Commission Library was said to be effective, and helped library service users to find the desired information.
\end{abstract}

Keywords: Recall and Precision, Information Retrieval System, Library, OPAC

\section{PENDAHULUAN}

Perkembangan dan kemajuan teknologi informasi selalu mengalami perubahan pada setiap zaman nya, terlebih saat ini memasuki era digital perubahan sangat cepat terjadi. Dalam dunia perpustakaan, manfaat dari adanya perkembangan dan kemajuan teknologi bisa dilihat dari adanya penemuan internet serta adanya informasi dalam bentuk digital yang dapat memberikan dampak positif yang sangat besar untuk perpustakaan. Perpustakaan Digital merupakan pengembangan dari sistem layanan informasi berbasis teknologi. Kelebihan yang didapat dari penggunaan perpustakaan digital dapat membantu kinerja dan proses penelusuran informasi secara tepat dan cepat, seperti dalam menemukan permasalahan menelusuri koleksi sebagai bahan informasi. Fitriani, dkk dalam penelitiannya mengatakan "Perpustakaan digital memberikan efek positif terhadap pengguna dalam pemberian informasi dari berbagai sumber yang berasal dari koleksi perpustakaan digital tersebut. Perpustakaan digital ini secara ekonomis lebih menguntungkan di bandingkan perpustakaan tradisional". Pada penelitian ini, peneliti menggunakan metoda $\mathrm{N}$-Gram untuk pengecekan pencarian berdasarkan konten pada perpustakaan digital. Dari hasil pengujian pencarian konten pada perpustakaan digital, diketahui dapat mempercepat proses pencarian karena adanya pengkoreksian pada setiap konten yang dicari, selain itu dapat mempercepat proses pencarian karena waktu yang dibutuhkan mesin pencari hanya setengah dari waktu yang dibutuhkan pencarian normal. Pencarian dokumen teks berbasis konten dengan memanfaatkan mesin pencari dapat memudahkan untuk mengetahui relevansi antara dokumen hasil pencarian dan kata kunci (Fitriani, Indrajit, \& Aryanti, 2017).

Pada penelitian yang dilakukan oleh Yusrawati mengatakan "Informasi yang disajikan oleh perpustakaan hendaklah menyajikan informasi atau sumber informasi yang dibutuhkan, yang berfungsi untuk menemukan informasi yang relevan dengan kebutuhan pemustaka". Pemustaka perpustakaan perguruan tinggi umumnya menggunakan literatur informasi yang beragam basis content (teks, audio, image, video) guna menunjang proses penelitian dan mampu menjawab setiap informasi yang dibutuhkan 
secara efektif dan efisien. Pada basis content seperti teks, image, video, visual, audio dan sebagainya saat ini mengalami perkembangan informasi yang sangat cepat. Oleh karena itu, perpustakaan perguruan tinggi membutuhkan sistem temu kembali informasi (information retrieval). Sistem temu kembali informasi yang digunakan saat ini memberikan hasil perolehan pencarian yang banyak, sehingga diperlukan waktu untuk menentukan hasil pencarian yang relevan. Sistem temu kembali informasi saat ini menghasilkan recall yang tinggi dan precision yang rendah. Recall yang tinggi maksudnya dokumen yang dihasilkan dalam penelusuran adalah banyak, sedangkan precision rendah berarti dokumen yang diharapkan sedikit ditemukan. Perpustakaan perguruan tinggi dituntut untuk memikirkan strategi pengembangan sistem temu kembali informasi, yang berbasis content dalam konteks sistem temu kembali informasi berbasis image (Yusrawati, 2017).

Komisi Nasional Hak Asasi Manusia (Komnas HAM) merupakan lembaga mandiri, yang kedudukannya setingkat dengan lembaga negara lainnya, yang berfungsi melaksanakan fungsi pengkajian, penelitian, penyuluhan, pemantauan dan mediasi. Banyaknya Akademisi, Peneliti dan Mahasiswa yang membutuhkan referensi sebagai bahan tulisan yang berkaitan dengan Hak Asasi Manusia, maka diperlukan sarana untuk memudahkan mereka untuk mendapatkan informasi terkait dengan Hak Asasi Manusia. Saat ini Komnas HAM mempunyai perpustakaan digital melalui portal

https://perpustakaan.komnasham.go.id/opackomnas

Perpustakaan Komnas HAM memanfaatkan kemajuan teknologi informasi dan katalog yaitu online public access catalog (OPAC) Senayan Library Management System (SLiMS) versi 8.3.1 Akasia. Sistem OPAC (Online Public Acsess Cataloguing) sudah mulai digunakan dibeberapa perpustakaan perguruan tinggi di Indonesia, dan menjadi serangkaian proses awal dari pengadaan temu kembali koleksi. Sistem temu kembali informasi dapat dijadikan sebagai alat penghubungan penelusuran informasi antara pengguna dan koleksi (Ernawati, 2018). Sistem temu kembali informasi di Perpustakaan Digital Komnas HAM, memberikan hasil perolehan pencarian yang banyak, sehingga diperlukan waktu untuk menentukan hasil pencarian yang relevan. Sayangnya, tidak seluruh literatur informasi dari berbagai content dapat ditelusuri dengan mudah. Dalam penelitian ini akan dibuktikan berapa tingkat efektifitas temu kembali aplikasi SLiMS (Senayan Library Management System) di Perpustakaan Digital Komnas HAM, dengan menghitung nilai recall dan precision. Dalam penelitian ini akan membahas efektivitas pada Perpustakaan Komnas
HAM, yang telah menggunakan OPAC Senayan Library Management System (SLiMS) versi 8.3.1 Akasia sejak tahun 2015. SLiMS adalah Open Source Sofware (OSS) berbasis web untuk memenuhi kebutuhan automasi perpustakaan SLiMS (Senayan Library Management System) skala kecil hingga skala besar. Dengan fitur yang cukup lengkap dan masih terus aktif dikembangkan, SLiMS (Senayan Library Management System) sangat cocok digunakan bagi perpustakaan yang memiliki koleksi banyak di lingkungan jaringan, baik jaringan lokal (intranet) maupun internet. Dengan adanya OPAC SLiMS (Senayan Library Management System) mempermudah cara pustakawan dan pengguna memanfaatkan fasilitas penelusuran katalog yang dahulu manual sekarang berubah dengan bantuan komputer.

OPAC merupakan bentuk dari sistem temu kembali informasi yang digunakan pengguna untuk menemukan informasi yang relevan pada sistem information retrieval (IR). Keberadaan OPAC (Online Public Access Cataloging) telah banyak membantu kinerja perpustakaan dalam memenuhi kebutuhan informasi para pemustaka. Sistem Teknologi OPAC (Online Public Access Cataloging) merupakan Penggabungan antara teknologi database, temu kembali informasi dan network. Sistem ini telah menghasilkan sistem temu kembali informasi yang cukup diandalkan di perpustakaan (Saufa \& Jamzanah, 2017). Dalam penelitian ini juga akan menggunakan pendekatan recall and precision, dengan batasan kriteria pencarian yaitu kriteria subyek. Kriteria pencarian tersebut dipilih karena query yang menggunakan tajuk subyek memiliki tingkat relevan/ketepatan yang signifikan antara subyek buku dengan isi buku.

\section{Information Retrieval System (IRS)}

Sistem temu kembali informasi berasal dari kata Information Retrieval System (IRS). Sistem temu kembali informasi adalah sebuah media layanan bagi pengguna untuk memperoleh informasi atau sumber informasi yang dibutuhkan oleh pengguna (Chowdhury, 2010). Temu kembali informasi merupakan sebuah metode untuk mengambil data terstruktur yang tersimpan dalam koleksi dokumen, kemudian menyediakan informasi yang diperlukan. Tujuan dari Information Retrieval yaitu untuk mengambil informasi serta menampilkan dokumen yang relevan dengan user dalam jumlah yang sangat besar (query) (Witanti, Rahmanto, \& Renaldi, 2016). Sistem temu kembali informasi memiliki keunggulan untuk menemukan informasi secara optimal, sehingga secara otomatis kebutuhan user dapat terpenuhi. Sistem temu kembali informasi adalah sebagai media layanan untuk memperoleh informasi atau sumber yang dibutuhkan oleh pengguna. Temu balik informasi berfungsi sebagai 
perantara kebutuhan informasi pengguna dengan sumber yang tersedia.

Sistem temu kembali diartikan sebagai suatu proses pencarian dokumen dengan menggunakan berbagai istilah pencarian untuk mendefinisikan dokumen sesuai dengan subyek yang diinginkan (Lancaster, 1979). Untuk mengetahui efektifitas temu kembali informasi harus menggunakan parameter evaluasi, dengan menjelaskan bagaimana sistem beroperasi atau mengetahui mengapa sistem berfungsi pada tingkat efisiensi tertentu. Efektivitas sistem temu kembali informasi merupakan pengukuran kemampuan dari sistem, untuk memanggil berbagai dokumen dari suatu database sesuai dengan permintaan pengguna. Ada dua hal penting yang biasanya digunakan dalam mengukur kemampuan sistem temu kembali informasi yaitu rasio atau perbandingan perolehan (recall) dan ketepatan (precision) (Yusrawati, 2017).

Mengetahui tingkat recall and precision dari sebuah sistem temu kembali informasi OPAC dapat menggambarkan tingkat efektivitas alat temu kembali informasi tersebut. Pada penelitian yang dilakukan oleh Haniati dengan mengambil studi kasus di Perpustakaan STIKES Ahmad Yani Yogyakarta, didapat nilai recal hasil penelitian melalui titik telusur judul yang mendapatkan nilai sangat efektif sebesar $88,73 \%$ dan melalui titik telusur subyek mendapatkan nilai efektif sebesar $65,09 \%$. Sedangkan efektivitas temu kembali berdasarkan precision melalui titik judul mendapatkan nilai efektif sebesar $96 \%$ dan melalui titik telusur subyek mendapatkan nilai efektif sebesar 90,3\%. Dari hasil penelitian tersebut diperoleh nilai precision yang lebih besar daripada nilai recallnya sehingga OPAC Perpustakaan STIKES Ahmad Yani Yogyakarta dapat dikatakan efektif sebagai alat temu kembali informasi dengan besar perolehan nilai persentase precision di atas 90\% (Haniati, 2013).

\section{Recall dan Precision}

Recall menurut Lancaster dalam Pendit adalah proporsi jumlah dokumen yang dapat ditemukan kembali oleh sebuah proses pencarian informasi (Pendit, 2008). Untuk mengukur recall dapat menggunakan rumus di bawah ini:

Tabel 1. Rumus menentukan recall dalam sistem temu kembali informasi

\begin{tabular}{|cc|}
\hline Recall $=$ & $\begin{array}{c}\text { Jumlah dokumen relevan yang } \\
\text { terpanggil (a) }\end{array}$ \\
\cline { 2 - 2 } & $\begin{array}{c}\text { Jumlah dokumen relevan yang ada di } \\
\text { dalam database }(\mathrm{a}+\mathrm{c})\end{array}$ \\
\hline
\end{tabular}

Sumber: Pendit (2008)
Precision merupakan sebuah ukuran yang mengukur tingkat proporsi jumlah dokumen yang dapat ditemukan kembali oleh sebuah proses pencarian dan dianggap relevan untuk kebutuhan pencarian informasi atau rasio jumlah dokumen relevan yang ditemukan dengan total jumlah dokumen yang ditemukan (Pendit, 2008). Untuk mengukur precision dapat diukur dengan menggunakan rumus sebagai berikut:

Tabel 2. Rumus menentukan precision dalam sistem temu kembali informasi

\begin{tabular}{|c|c|}
\hline \multirow[t]{2}{*}{ Precision $=$} & $\begin{array}{c}\text { Jumlah dokumen relevan yang } \\
\text { terpanggil (a) }\end{array}$ \\
\hline & $\begin{array}{c}\text { Jumlah dokumen relevan yang } \\
\text { ada di dalam database }(a+b)\end{array}$ \\
\hline
\end{tabular}

Tabel 3. Matriks Recall dan Precision

\begin{tabular}{llll}
\hline & Relevant & $\begin{array}{c}\text { Not } \\
\text { Relevant }\end{array}$ & Total \\
\hline Retrieved & $\mathrm{a}($ hits $)$ & $\mathrm{b}$ (noise) & $\mathrm{a}+\mathrm{b}$ \\
$\begin{array}{l}\text { Not } \\
\text { Retrieved }\end{array}$ & $\mathrm{c}($ misses) & $\mathrm{d}$ (reject) & $\mathrm{c}+\mathrm{d}$ \\
$\begin{array}{l}\text { Total } \\
\text { notal }\end{array}$ & $\mathrm{a}+\mathrm{c}$ & $\mathrm{b}+\mathrm{d}$ & $\mathrm{a}+\mathrm{b}+\mathrm{c}+\mathrm{d}$ \\
\hline
\end{tabular}

Sumber: Pendit (2008)

Keterangan:

a (hits) $=$ dokumen yang relevan

$\mathrm{b}$ (noise $)=$ dokumen yang tidak relevan

c (misses) $=$ dokumen relevan yang tidak ditemukan

$\mathrm{d}($ reject $)=$ dokumen tidak relevan yang tidak ditemukan

\section{Efektivitas Recall dan Precision}

Efektivitas adalah kemampuan untuk memilih tujuan dengan memanfaatkan sarana dan prasarana yang tepat untuk mencapai tujuan. Efektivitas sistem temu kembali informasi dapat diartikan kemampuan dari sebuah sistem untuk memanggil berbagai dokumen dari suatu database sesuai dengan permintaan pengguna (Pao, 1989). Pengukuran efektivitas suatu sistem temu kembali informasi dapat dilakukan dengan perhitungan terhadap nilai perolehan (recall), nilai ketepatan (precision), dan jatuhan semu (fallout) (JeanTagueSutcliffe, 1992). Namun di antara ketiga metode tersebut, perhitungan ketepatan (precision) merupakan cara yang paling umum digunakan (JeanTague-Sutcliffe, 1992). Lancaster memberikan penilaian untuk mengukur tingkat precision pada penilaian efektivitas suatu sistem temu kembali informasi dengan ukuran angka dan mengkategorikannya menjadi precision rendah yaitu tidak efektif, precision sedang berarti kurang efektif, dan precision tinggi yang berarti efektif (Lancaster, 1979). Berikut tabel penilaiannya: 
Tabel 4. Penilaian efektivitas precision sistem temu kembali informasi

\begin{tabular}{cc}
\hline $\mathbf{0}-\mathbf{0 , 3 3}$ & $\begin{array}{c}\text { Precision rendah Tidak } \\
\text { efektif }\end{array}$ \\
\hline $\mathbf{0 , 3 4}-\mathbf{0 , 6 7}$ & Precision sedang Kurang efektif \\
$\mathbf{0 , 6 8}-\mathbf{1 , 0 0}$ & Precision tinggi Efektif \\
\hline Sumber: Pendit (2008) \\
Rumusan Masalah
\end{tabular}

Dari uraian latar belakang masalah yang telah dipaparkan di atas, maka peneliti membuat rumusan masalah berdasarkan maksud dari diadakannya penelitian ini. Dalam sebuah penelitian rumusan masalah yang digunakan yaitu untuk memudahkan peneliti dalam menganalisa objek yang diteliti. Maka, rumusan masalah penelitian ini adalah sebagai berikut:

a. Bagaimana recall and precision sistem temu kembali informasi OPAC Perpustakaan Komnas HAM?

b. Apakah sistem temu kembali informasi OPAC Perpustakaan Komnas HAM efektif sebagai sistem temu kembali informasi?

\section{METODOLOGI PENELITIAN}

Penelitian ini adalah penelitan kuantitatif dengan jenis pendekatan eksperimen. Metode pengumpulan data yang digunakan adalah observasi, tes pencarian data, dokumentasi, dan wawancara. Selain itu, penulis menggunakan studi pustaka dalam mencari berbagai referensi yang berhubungan dengan penelitian yang diambil. Subjek penelitian yang dimaksudkan adalah Katalog Induk Terpasang Perpustakaan Komnas HAM. Sedangkan objek penelitiannya adalah pencarian menggunakan tajuk subyek, yang memiliki tingkat relevan/ketepatan yang signifikan antara subyek buku dengan isi buku.

Metode pengumpulan data yang dilakukan adalah dengan melakukan penelusuran pada perpustakaan digital Komnas HAM melalui portal https://perpustakaan.komnasham.go.id/opackomnas.

Setiap istilah pencarian/kata kunci yang digunakan dalam proses penelusuran, hasilnya berupa sejumlah data katalog. Data katalog yang diperoleh kemudian dianalisa dan dicatat data mana yang sangat relevan, kurang relevan dan tidak relevan dengan kebutuhan informasi (topik) yang dicari. Untuk menentukan dokumen yang ditemukan sangat relevan, kurang relevan atau tidak relevan dilakukan dengan cara menganalisis setiap dokumen berdasarkan nomor klasifikasi, judul dan subjek buku yang ada. Masingmasing data dicatat dalam sebuah kolom dalam tabel perolehan dari kegiatan penelusuran katalog induk terpasang. Kemudian akan dilakukan perhitungan recall dan precision untuk mengetahui tingkat efektifitas temu kembali aplikasi SLiMS (Senayan Library Management System) pada Perpustakaan Digital Komnas HAM.

\section{HASIL DAN PEMBAHASAN}

1. Analisis dan Pembahasan Recall dan Precision Perhitungan recall dan precision bertujuan untuk mengetahui efektifitas sistem temu kembali informasi melalui aplikasi SLiMS (Senayan Library Management System) diperpustakaan Komnas HAM. Untuk menghitung recall dan precision dilakukan dengan eksperimen dengan memasukan kata kunci yang digunakan pengguna untuk menelusur informasi melalui aplikasi SLiMS di perpustakaan Komnas HAM melalui fitur pencarian sederhana.

Eksperimen melalui fitur pencarian sederhana dikarenakan fitur pencarian sederhana lebih mudah dilakukan. Pengguna cukup memasukan kata kunci kedalam kotak pencarian yang telah tersedia di OPAC (Online Public Access Catalogue) sistem temu kembali aplikasi SLiMS. Kata kunci tersebut akan dicocokan dengan hal metadata oleh sistem. Jika ada hal metadata yang cocok dengan kata kunci yang dimasukan, maka metadata tersebut akan dimunculkan oleh sistem temu kembali aplikasi SLiMS (Senayan Library Management System) .

Dari hasil penelitian didapatkan data yang dicari oleh pengguna perpustakaan yang dilihat dalam tabel sebagai berikut:

Tabel 5. Koleksi Yang Ditelusuri

\begin{tabular}{ccl}
\hline No & Nama & Koleksi yang dicari \\
\hline $\mathbf{1}$ & Pengguna 1 & Hak Tanah \\
$\mathbf{2}$ & Pengguna 2 & Perdagangan Manusia \\
$\mathbf{3}$ & Pengguna 3 & Pelanggaran HAM \\
$\mathbf{4}$ & Pengguna 4 & Penyandang \\
& & Disabilitas \\
$\mathbf{5}$ & Pengguna 5 & Peristiwa 1965 \\
$\mathbf{6}$ & Pengguna 6 & Sengketa tanah \\
$\mathbf{7}$ & Pengguna 7 & Kasus Masa Lalu \\
$\mathbf{8}$ & Pengguna 8 & Hukuman Mati \\
$\mathbf{9}$ & Pengguna 9 & Sipil dan Politik \\
$\mathbf{1 0}$ & Pengguna 10 & Genosida \\
\hline
\end{tabular}

\section{Hasil Tes Recall dan Precision}

Recall adalah proporsi jumlah dokumen yang ditemukan kembali oleh sebuah proses pencarian dalam sistem temu kembali informasi. Pricision adalah proporsi jumlah dokumen yang ditemukan dan dianggap relevan untuk kebutuhan pencari informasi (Pendit, 2008).

Ukuran recall dan precision ini juga bergantung pada apa yang sesungguhnya dimaksud dengan "dokumen yang relevan" itu dan bagaimana memastikan relevan tidaknya dokumen. Berikut adalah tabel interpretasi relevan dan tidak relevan:

Tabel 6. Interpretasi Relevan dan Tidak Relevan

\begin{tabular}{ccc}
\hline Katagori & Definisi & Intrepretasi \\
\hline Relevan & Dokumen & Saya kecewa \\
\hline
\end{tabular}




\begin{tabular}{lll}
\hline & merupakan & jika sistem \\
& tanggapan & gagal \\
& langsung dari & menemukan \\
& pertanyaan & dokumen ini. \\
Tidak & Dokumen & Saya kecewa \\
Relevan & tidak relevan & jika sistem \\
& dengan & menemukan \\
& pertanyaan & dokumen ini \\
\hline
\end{tabular}

Dari hasil tes data penelitian tentang recall dan precision, maka ditemukan hasil penelitian sebagai berikut:

Tabel 7. Hasil Interpretasi Relevan dan Tidak Relevan

\begin{tabular}{|c|c|c|c|c|c|c|}
\hline $\begin{array}{l}\text { No. } \\
\text { Tes }\end{array}$ & $\begin{array}{c}\text { Koleksi yang } \\
\text { dicari }\end{array}$ & Ditemukan & Relevan & $\begin{array}{c}\text { Tidak } \\
\text { relevan }\end{array}$ & Keterangan & $\begin{array}{c}\text { Waktu } \\
\text { pencarian }\end{array}$ \\
\hline 1 & $\begin{array}{l}\text { Sengketa } \\
\text { tanah }\end{array}$ & 40 & 40 & 0 & $\begin{array}{ll}\text { Responden menemukan } & 40 \\
\text { buku, semua buku relevan } & \end{array}$ & 6,30988 detik \\
\hline 2 & $\begin{array}{l}\text { Perdagangan } \\
\text { Manusia }\end{array}$ & 25 & 25 & 0 & $\begin{array}{l}\text { Responden menemukan } 23 \\
\text { buku, semua buku relevan }\end{array}$ & 6,27751 detik \\
\hline 3 & $\begin{array}{l}\text { Pelanggaran } \\
\text { HAM }\end{array}$ & 1246 & 1216 & 30 & $\begin{array}{l}\text { Dari } 1246 \text { hasil pencarian, } \\
\text { responden menemukan } 1216 \\
\text { yang relevan dan } 30 \text { yang } \\
\text { tidak relevan }\end{array}$ & 6,96597 detik \\
\hline 4 & $\begin{array}{l}\text { Penyandang } \\
\text { Disabilitas }\end{array}$ & 27 & 27 & 0 & $\begin{array}{l}\text { Responden menemukan } 27 \\
\text { buku, semua buku relevan }\end{array}$ & 5,36801 detik \\
\hline 5 & $\begin{array}{l}\text { Peristiwa } \\
1965\end{array}$ & 17 & 17 & 0 & $\begin{array}{l}\text { Responden menemukan } 17 \\
\text { buku, semua buku relevan }\end{array}$ & 7,57302 detik \\
\hline 6 & $\begin{array}{l}\text { Sengketa } \\
\text { tanah }\end{array}$ & 25 & 25 & 0 & $\begin{array}{l}\text { Dari } 25 \text { hasil pencarian, } \\
\text { responden menemukan } 24 \\
\text { yang relevan dan } 1 \text { yang tidak } \\
\text { relevan }\end{array}$ & 5,24432 detik \\
\hline 7 & $\begin{array}{l}\text { Kasus Masa } \\
\text { Lalu }\end{array}$ & 2 & 2 & 0 & $\begin{array}{l}\text { Responden menemukan } 2 \\
\text { buku, semua buku relevan }\end{array}$ & 6,22227 detik \\
\hline 8 & $\begin{array}{l}\text { Hukuman } \\
\text { Mati }\end{array}$ & 20 & 20 & 0 & $\begin{array}{l}\text { Responden menemukan } 20 \\
\text { buku, semua buku relevan }\end{array}$ & 6,60824 detik \\
\hline 9 & $\begin{array}{l}\text { Sipil dan } \\
\text { Politik }\end{array}$ & 191 & 188 & 3 & $\begin{array}{l}\text { Dari } 191 \text { hasil pencarian, } \\
\text { responden menemukan } 188 \\
\text { yang relevan dan } 3 \text { yang tidak } \\
\text { relevan }\end{array}$ & 16,63874 detik \\
\hline 10 & Genosida & 31 & 31 & 0 & $\begin{array}{l}\text { Responden menemukan } 31 \\
\text { buku, semua buku relevan }\end{array}$ & 3,1097 detik \\
\hline
\end{tabular}

Untuk mengetahui bagaimana recall dan precision, pada sistem temu kembali informasi aplikasi SLiMS (Senayan Library Management System) di perpustakaan Komnas HAM, maka penulis mengolah dan menganalisis data di atas, dengan mengacu pada rumus yang sudah penulis paparkan sebelumnya sebagai berikut:

Tabel 8. Matriks Recall dan Precision

\begin{tabular}{llll}
\hline & Relevan & $\begin{array}{l}\text { Tidak } \\
\text { Relevan }\end{array}$ & Total \\
\hline $\begin{array}{l}\text { Ditemukan } \\
\text { Tidak }\end{array}$ & $\mathrm{a}$ (hits) & $\mathrm{b}$ (noise) & $\mathrm{a}+\mathrm{b}$ \\
ditemukan & $\mathrm{c}$ (misses) & $\mathrm{d}$ (rejected) & $\mathrm{c}+\mathrm{d}$ \\
Total & $\mathrm{a}+\mathrm{c}$ & $\mathrm{b}+\mathrm{d}$ & $\mathrm{a}+\mathrm{b}+$ \\
& & & $\mathrm{c}+\mathrm{d}$ \\
\hline
\end{tabular}

Berdasarkan tabel tersebut, rumus recall dan pricision menjadi :

Recall $=[\mathrm{a} /(\mathrm{a}+\mathrm{c})] \times 100$

Precision $=[\mathrm{a} /(\mathrm{a}+\mathrm{b})] \times 100$

Untuk menentukan dokumen relevan yang tidak ditemukan di dalam proses pencarian oleh pengguna, penulis melakukan pencarian lanjutan dokumen-dokumen lain yang relevan dengan menggunakan buku induk. Layak tidaknya dokumen yang ditemukan dalam proses pencarian lanjutan merupakan hasil interperasi subyektif penulis berdasarkan hasil diskusi dengan pengguna dan pustakawan. Hasil temuan dokumen relevan yang tidak ditemukan oleh pengguna ditampilkan pada tabel di bawah ini: 
Tabel 9. Hasil Perhitungan Matriks Recall dan Precision

\begin{tabular}{cccccccc}
\hline No & $\begin{array}{c}\text { Relevan } \\
(\mathrm{a})\end{array}$ & $\begin{array}{c}\text { Tidak } \\
\text { relevan } \\
(\mathrm{b})\end{array}$ & $\begin{array}{c}\text { Total } \\
(\mathrm{a}+\mathrm{b})\end{array}$ & $\begin{array}{c}\text { Tidak } \\
\text { ditemukan } \\
(\mathrm{c})\end{array}$ & $\begin{array}{c}\text { Total } \\
(\mathrm{a}+\mathrm{c})\end{array}$ & $\begin{array}{c}\text { Recall } \\
|\mathrm{a} /(\mathrm{a}+\mathrm{c})| \mathrm{x} 100 \%\end{array}$ & $\begin{array}{c}\text { Precision } \\
|\mathrm{a} /(\mathrm{a}+\mathrm{b})| \mathrm{x} 100 \%\end{array}$ \\
\hline $\mathbf{1}$ & 40 & 0 & 40 & 0 & 40 & 100 & 100 \\
$\mathbf{2}$ & 25 & 0 & 25 & 0 & 25 & 100 & 100 \\
$\mathbf{3}$ & 1216 & 30 & 1246 & 11 & 1227 & 99.10350448 & 97.59229535 \\
$\mathbf{4}$ & 27 & 0 & 27 & 0 & 27 & 100 & 100 \\
$\mathbf{5}$ & 17 & 0 & 17 & 0 & 17 & 100 & 100 \\
$\mathbf{6}$ & 25 & 0 & 25 & 0 & 25 & 100 & 100 \\
$\mathbf{7}$ & 2 & 0 & 2 & 0 & 2 & 100 & 100 \\
$\mathbf{8}$ & 20 & 0 & 20 & 0 & 20 & 100 & 100 \\
$\mathbf{9}$ & 185 & 3 & 188 & 2 & 187 & 98.93048128 & 98.40425532 \\
$\mathbf{1 0}$ & 31 & 0 & 31 & 0 & 31 & 100 & 100 \\
& & & & & Rata - Rata & 99.80339858 & 99.59965507 \\
\hline
\end{tabular}

Keterangan:

$\begin{array}{ll}\text { a: Hits } & \text { P: Precision } \\ \text { b: Noise } & \text { R: Recall } \\ \text { c: } \text { Missed } & \end{array}$

Dari tabel diatas didapat Rata-rata nilai Precision adalah sebesar 99,6\% dan nilai recall-nya adalah sebesar $99,8 \%$ dari skala $0 \%-100 \%$, sehingga dapat diketahui bahwa nilai precision lebih lebih rendah dari pada nilai recall berdasarkan kata kunci yang digunakan oleh pengguna jasa perpustakaan Komnas HAM. Walaupun nilai precision lebih rendah dari pada nilai recall, tingkat keefektifan dari sistem temu kembali informasi aplikasi SLiMS (Senayan Library Management System) sudah dikatakan efektif. Keefektifan suatu sistem temu kembali informasi dinilai berdasarkan teori yang dicetuskan oleh Lancaster (1991) dalam Pendit (Pendit, 2008) yaitu relevan dan tidak relevan, jadi efektifitas temu kembali informasi dibedakan menjadi efektif jika nilai di atas $50 \%$ dan tidak efektif jika nilai dibawah nilai 50\%. Kemudian Kondisi ideal dari keefektifan suatu sistem temu kembali informasi adalah apabila rasio recall dan precision sama besarnya (1:1) (Pao, 1989). Selain itu, suatu sistem temu kembali dinyatakan efektif apabila hasil penelusuran mampu menunjukkan ketepatan (precision) yang tinggi sekalipun perolehannya (recall) rendah (Rowley, 1990).

Dari sejumlah kata kunci yang dicari, kata kunci yang nilai recall dan precision yang tinggi terdapat pada kata kunci "Hak Tanah, Perdagangan Manusia, Kekerasan Anak, Penyandang Disabilitas, Peristiwa 1965, Sengketa tanah, Kasus Masa Lalu, Hukuman Mati, Genosida", yang nilai recall dan precision adalah $100 \%$. Hal tersebut dikarenakan jumlah yang relevan lebih besar atau seimbang jika dibandingkan dengan yang tidak relevan. Hal ini membuktikan bahwa nilai recall dan precision tinggi karena sistem dapat mengendalikan pencarian yang dilakukan dengan menggunakan kumpulan istilah atau kata kunci yang lebih spesifik. Namun, kata yang digunakan haruslah sesuai dengan hal metadata perpustakaan. Sedangkan yang mempunyai nilai precision paling rendah adalah kata kunci "Pelanggaran HAM", yang nilai recall 99\% dan precision $97,6 \%$ hal tersebut dikarenakan jumlah yang tidak relevan lebih besar atau tidak seimbang dari jumlah yang relevan. Nilai recall dan precision tidak seimbang disebabkan oleh faktor-faktor, diantaranya: terbatasnya koleksi yang dimiliki, masih adanya koleksi yang belum diinput, tidak sesuainya kata kunci yang digunakan oleh penggua dalam pencarian dengan kata kunci yang diinput, pengguna belum sepenuhnya memahami aplikasi sistem temu kembali yang digunakan, kata kunci yang digunakan dalam pencarian masih terlalu luas (general) dan masih banyak faktor-faktor lainnya.

Secara umum pengguna menyatakan ada beberapa dokumen yang diperoleh dinilai tidak relevan. Artinya sebagian besar dokumen yang diperoleh berhubungan dengan subjek yang dicari, tetapi tidak secara langsung menjawab dari keinginan pengguna (user). Penilaian ini dapat disebabkan cakupan istilah pencarian terlalu luas, sehingga dokumen yang tidak berhubungan langsung dengan subjek yang diinginkan turut terambil. Disamping itu, tidak ada atau sedikitnya deskripsi dokumen yang disertai abstrak membuat pengguna sulit menduga isi 
dokumen dengan hanya membaca judul dari dokumen yang terambil. Penelitian ini juga membuktikan bahwa hubungan antara recall dan precision tidaklah berbanding terbalik, jika seluruh dokumen yang relevan berhasil ditemukan, hal ini terjadi karena pencarian menggunakan kata kunci yang sesuai dengan salah satu dokumen dan sistem mengindeks istilah sesuai dengan hal metadata dokumen yang dimasukan oleh pustakawan. Sehingga dokumen yang dimaksud dapat ditemukan kembali oleh sistem.

Sedangkan untuk mengetahui apakah aplikasi SLiMS sudah sepenuhnya membantu para pengguna jika dijadikan sebagai suatu aplikasi perpustakaan sebagaimana yang telah diterapkan di perpustakaan Komnas HAM dapat dilihat juga dari tingkat akurasi atau ketepatan dalam pencarian data, yaitu sebuah faktor yang mempunyai nilai, yang membuat pencari informasi mendapatkan ketepatan informasi yang dibutuhkan oleh pengguna dari seluruh informasi yang ada dalam database. Dari 10 kata kunci yang dicari oleh pengguna di database, ditemukan ratarata precision sebesar $96,6 \%$, dari nilai ini berarti sistem yang ada sudah mempunyaai indikator akurasi yang sudah efektif dalam pencarian data/informasi di aplikasi SLiMS perpustakaan Komnas HAM. Hal tersebut menunjukan bahwa sistem temu kembali pada perpustakaan Komnas HAM sudah memenuhi syarat sebagai sebuah mesin pencari (search engine) yang mempunyaai nilai akurasi tinggi. Berdasarkan hal di atas menunjukan bahwa penerapan sistem temu kembali aplikasi SLiMS di perpustakaan Komnas HAM, sudah dapat dikatakan membantu pengguna layanan perpustakaan untuk lebih mudah mendapatkan informasi yang sesuai dengan kebutuhan pencari informasi.

\section{KESIMPULAN}

Berdasarkan hasil eksperimen yang dilakukan, maka dapat diambil kesimpulan bahwa tingkat efektifitas temu kembali aplikasi SLiMS (Senayan Library Management System) di Komnas HAM sudah bisa dikatakan efektif. Hal ini terlihat dari rata-rata tingkat perolehan (recall) sebesar 99,8\% dan ratarata tingkat ketepatan (precision) yang dihasilkan sebesar 99,6\%. Dari sejumlah kata kunci yang dicari, kata kunci yang nilai recall dan precision yang tinggi terdapat pada kata kunci "Hak Tanah, Perdagangan Manusia, Kekerasan Anak, Penyandang Disabilitas, Peristiwa 1965, Sengketa tanah, Kasus Masa Lalu, Hukuman Mati, Genosida" mendapat recall dan precision $100 \%$. Hal tersebut dikarenakan jumlah yang relevan lebih besar atau seimbang jika dibandingkan dengan yang tidak relevan, dan membuktikan bahwa nilai recall dan precision tinggi karena sistem dapat mengendalikan pencarian yang dilakukan dengan menggunakan kumpulan istilah atau kata kunci yang lebih spesifik dan kata yang digunakan sesuai dengan hal metadata perpustakaan.
Sedangkan yang mempunyai nilai precision paling rendah adalah kata kunci "Pelanggaran HAM", yang nilai recall $99 \%$ dan precision 97,6\% hal tersebut dikarenakan jumlah yang tidak relevan lebih besar atau tidak seimbang dari jumlah yang relevan. Nilai recall dan precision tidak seimbang disebabkan oleh faktor-faktor, diantaranya: terbatasnya koleksi yang dimiliki, masih adanya koleksi yang belum diinput, tidak sesuainya kata kunci yang digunakan oleh pengguna dalam pencarian dengan kata kunci yang diinput, pengguna belum sepenuhnya memahami aplikasi sistem temu kembali yang digunakan, kata kunci yang digunakan dalam pencarian masih terlalu luas (general) dan masih banyak faktor-faktor lainnya.

\section{REFERENSI}

Chowdhury, G. G. (2010). Introduction to Modern Information Retrieval (Third Edit). London: Facet Publishing.

Ernawati. (2018). Perpustakaan Digital Dalam Temu Kembali Informasi Dengan OPAC. JIPI (Jurnal Ilmu Perpustakaan Dan Informasi), 3(1), 103-120.

Fitriani, E., Indrajit, R. E., \& Aryanti, R. (2017). Penerapan Model Information Retrieval Untuk Pencarian Konten Pada Perpustakaan Digital. Perspektif, XV(2), 170-176.

Haniati, U. (2013). Efektivitas OPAC Perpustakaan Stikes Ahmad Yani Yogyakarta (Tinjauan Recall dan Precision dengan Pendekatan Judul dan Subjek). UIN Sunan Kalijaga, Yogyakarta.

JeanTague-Sutcliffe. (1992). The Pragmatics of Information Retrieval Experimentation, Revisited. Information Processing \& Management, 28(4), 467-490.

Lancaster, F. W. (1979). Information Retrieval System: Characteristics, Testing, and Evaluation (2 nd Editi). New York: John Wiley.

Pao, M. L. (1989). Concepts of Information Retrieval. Colorado: Englewood Libraries Unlimited.

Pendit, P. L. (2008). Perpustakaan Digital dari A sampai Z. Jakarta: Citra Karya Karsa Mandiri.

Rowley, J. (1990). Abstracting and Indexing (Second Edi). London: Clive Bingley.

Saufa, A. F., \& Jamzanah, W. (2017). Evaluasi Sistem Temu Kembali Informasi Koha di Perpustakaan Universitas Muhammadiyah Surakarta (UMS). Khizanah Al-Hikmah: Jurnal Ilmu Perpustakaan, Informasi, Dan Kearsipan, 5(2), 140-151.

Witanti, W., Rahmanto, H., \& Renaldi, F. (2016). Pembangunan Sistem Temu Balik Informasi (Information Retrieval) Dalam Pemilihan Pemain Sepak Bola Berkualitas di Indonesia Berbasis Analisis Sentimen. Seminar Nasional 
Teknologi Informasi Dan Komunikasi 2016 (SENTIKA 2016), 484-491.

Yusrawati. (2017). Strategi Pengembangan Sistem Temu Kembali Informasi Berbasis "Image" di Perpustakaan Perguruan Tinggi. LIBRIA, 9(1), 53-68.

\section{PROFIL PENULIS}

Martin, S.Kom. Menempuh pendidikan Sarjana (S1) di Sekolah Tinggi Manajemen Informatika dan Komputer Nusa Mandiri Program Studi Teknik Informatika lulus tahun 2009, saat ini sedang menempuh pendidikan Magister (S2) Ilmu Komputer di Sekolah Tinggi Manajemen Informatika dan Komputer Nusa Mandiri. Aktif bekerja sebagai Analis Sistem Informasi di Komisi
Nasional Hak Asasi Manusia (Komnas HAM) RI dari tahun 2014 sampai sekarang.

Lala Nilawati, M.Kom. Menempuh pendidikan Sarjana (S1) di Sekolah Tinggi Manajemen Informatika dan Komputer Nusa Mandiri, Program Studi Sistem Informasi lulus tahun 2010, dan Program Magister (S2) Sekolah Tinggi Manajemen Informatika dan Komputer Nusa Mandiri, Program Studi Ilmu Komputer lulus tahun 2015. Pernah bekerja menjadi Asisten Laboratorium Komputer Bina Sarana Informatika tahun 2006 sampai tahun 2007, tahun 2008 sampai sekarang aktif bekerja menjadi staff pengajar (dosen) di Universitas Bina Sarana Informatika. 